\title{
0 Governo dos Sentimentos Morais no Século XVIII
}

\author{
Daniel Pereira Andrade
}

Fundação Getulio Vargas (FGV-SP), São Paulo, SP, Brasil. E-mail: dpaaa@hotmail.com

\begin{abstract}
T os séculos XVII e XVIII, emergiu de maneira inseparável do de1 bate sobre as formas de governo uma série de tratados e escritos sobre as paixões. O enunciado de que as paixões, e não a razão inativa, influenciavam decisivamente a vontade e eram os verdadeiros motores das condutas humanas circulou tanto entre vertentes teológicas e pastorais da Reforma e Contrarreforma, como entre pensadores políticos e conselheiros de Príncipes. A vida "emocional" constituía-se, assim, como objeto privilegiado exatamente no momento em que o problema do governo era despertado por estes dois amplos processos europeus: a unificação política dos Estados nacionais e a desagregação religiosa Ocidental, processos que recorrentemente cruzavam suas fronteiras e se articulavam, como nas guerras religiosas (Foucault, 2004a:92).
\end{abstract}

As paixões permitiam justamente a circulação entre estratégias pastorais e políticas, transformando-se semântica e normativamente conforme os próprios deslocamentos do governo. Se de um lado explicavam a natureza corrompida do homem após o pecado original e eram objeto de controle pelas diferentes práticas de direção das almas visando a salvação, de outro lado ofereciam uma grade de leitura pessimista dos comportamentos efetivos e técnicas de manipulação de súditos e adversários políticos. Ademais, as paixões constituíam objeto de auto-

DADOS - Revista de Ciências Sociais, Rio de Janeiro, vol. 59, n-1, 2016, pp. 233 a 269.

http://dx.doi.org/10.1590/00115258201676 
controle tanto para o governante que queria ser justo e/ou prudente, quanto para o homem comum que pretendesse atravessar o mundo turbulento da época sem cair em desgraça terrena ou celeste.

As paixões encontravam-se, assim, no centro do problema do governo tal como era entendido na época. Segundo Foucault (1995:234), governo não se

referia apenas às estruturas políticas e à gestão dos Estados; mas designava a maneira de dirigir a conduta dos indivíduos ou dos grupos [...]. Ele não recobria apenas formas instituídas e legítimas de sujeição política ou econômica; mas modos de ação mais ou menos refletidos e calculados, porém todos destinados a agir sobre as possibilidades de ação dos outros indivíduos. Governar, neste sentido, [era] estruturar o eventual campo de ação dos outros.

O governo incluía também o governo de si mesmo, que diz respeito à moral, não sendo apenas o governo de uns sobre os outros através da colonização das técnicas de si, mas também um trabalho do sujeito sobre si próprio em sua articulação com os outros. Enfim, era o "contato entre as tecnologias de dominação dos demais e as referidas a si mesmo" (Foucault, 1990:49).

Exatamente pela importância das paixões para o governo das condutas, constituiu-se um enorme debate a respeito das designações e definições do que podemos chamar anacronicamente de vida "emocional". As diferentes artes de governo, ao explicarem o que é a "emoção", quais são as suas fontes causadoras, como ela se relaciona com as demais faculdades da mente e com o corpo e como ela determina as condutas, estabeleciam dispositivos de poder "emocional" inseparáveis de um ideal antropológico, de laço social e de ordem visada. Por isso, cada concepção geral sobre a vida "emocional" estava ligada a um estilo de intervenção, com determinados objetos, técnicas, finalidades e regras "emocionais" e expressivas que incidem sobre "emoções" específicas ao avaliar e estabelecer o que, quando e como se deve sentir e/ou manifestar emocionalmente (Hochschild, 2003:82-83).

O poder "emocional" não é, portanto, homogêneo. Ele não possui uma história linear, mas se constitui nos embates pela definição teóriconormativa da vida "emocional". Concepções como paixões, sentimentos morais e emoções possuem usos teóricos e estratégicos autônomos e concorrentes e cada um deles pode, inclusive, sofrer variações próprias. 
Tal diferenciação implica um cuidado metodológico para evitar o anacronismo. Em primeiro lugar, quando propomos fazer uma história do governo da vida "emocional", colocamos, prudentemente, o termo "emoções" e seus derivados entre aspas. A ideia é diferenciar pelas aspas quando estamos nos referindo de modo genérico ao conjunto das diferentes concepções e, na sua ausência, quando estamos nos referindo ao uso histórico particular e delimitado do termo, que emergiu apenas no século XIX (Dixon, 2003). Como "emoção" é a designação adotada hoje pela sociologia, conservamo-la como termo genérico, e filiamo-nos teoricamente ao construcionismo social, o qual afirma que as "emoções", embora corporais, são produzidas por meio de discursos, práticas, normas e relações (Harré, 1986). Deste modo, as "emoções" já são pensadas a partir de uma determinada concepção, mas esta unidade é constituída apenas no método de nossa análise, e não deve nos levar a ignorar que no passado houve múltiplas concepções, ligadas a diferentes discursos e estratégias.

O objetivo deste artigo é realizar a genealogia de parte dessa história do poder "emocional", mais precisamente daquela vinculada à concepção de sentimentos morais. Pretende-se compreender como esta noção emergiu e como foi problematizada em relação à sua fonte causadora, ao corpo (individual ou coletivo), a outras faculdades da alma (percepção moral e razão) e às condutas que desencadeava, e, deste modo, como se prestou a um novo uso estratégico (com determinados objetos, técnicas, finalidades e regras emocionais e expressivas) ao longo dos discursos de governamentalidade britânicos do século XVIII.

Mesmo que no século XVII o pensamento político britânico problematizasse, por razões históricas, preferencialmente questões referentes à soberania (direito, constituição e liberdade), ainda assim cabe enquadrá-lo nos discursos de governamentalidade tais como definidos por Foucault (que é nossa opção metodológica), pois o discurso propriamente governamental sobre a Razão de Estado foi reivindicado tanto por parte de reis que almejavam o absolutismo, como James I, como pela House of Commons, sendo parte do arsenal de argumentos utilizados nas disputas pela soberania (Mosse, 1957:12-13). Decidida a disputa em prol do Parlamento, a questão do governo no século XVIII associou a preocupação com o limite do poder do soberano com a busca de uma concepção de laços sociais que pacificasse uma sociedade que acabara de sair de guerras religiosas. Como esse discurso assumia que as paixões eram a base das condutas e laços humanos, ele buscou 
justamente uma normatividade "emocional" não religiosa como princípio de coesão social autônoma em relação ao soberano. A temática dos sentimentos morais, do ponto de vista político, apareceu como alternativa a uma tripla ameaça: 1) às concepções puritanas ou católicas das paixões e da graça que estariam na base teológica e pastoral das lutas religiosas; 2) a uma concepção hobbesiana de paixões egoístas que levariam à guerra de todos contra todos e legitimaria assim a constituição de um poder soberano ilimitado; e 3) a uma concepção de paixões egoístas que uniriam os homens por laços de interesse constituídos sobretudo na esfera econômica, tendo efeito simultaneamente corruptor sobre as virtudes individuais e apaziguador sobre a sociedade, dispensando o soberano absoluto, mas contrariando a moral cristã, como aparece em Bernard Mandeville (1934 [1714]; 1996).

Assim sendo, é preciso inicialmente retraçar, ainda que sucintamente, como surgiu e se desenvolveu a temática das paixões no século XVII para, em seguida, compreender como os sentimentos morais surgiram no século seguinte como resposta às diferentes vertentes de governo passional e se desenvolveram por meio de figuras teóricas como o senso moral, a simpatia e, finalmente, os sentimentos sociais, para constituir uma normatividade alternativa e, por consequência, um novo tipo de laço social e ordem política.

\section{O GOVERNO DAS PAIXÕES NO SÉCULO XVII}

Antes de adentrar o campo propriamente político, a preocupação com as paixões no final do século XVI se devia à questão dogmática mais importante das disputas religiosas entre protestantes e católicos e também entre as diferentes vertentes católicas da Contrarreforma: a querela da graça. Tais disputas teológicas possuíam importância decisiva para as práticas de direção espiritual a serem adotadas na terra com vistas à salvação da alma.

A releitura de Santo Agostinho feita pelos reformadores, especialmente por Martinho Lutero e, posteriormente, por Calvino, afirmava que a única via da salvação seria a graça divina, na medida em que o livre arbítrio humano seria na verdade um servo arbítrio (serf arbitre), pois, após o pecado original, a natureza do homem estaria inteiramente corrompida pela concupiscência e conduziria o fiel necessariamente ao pecado e à danação. Devido à anulação dos sacramentos católicos e ao deslocamento para uma ascese fundada na consciência interna dos 
eleitos que a ênfase teológica na predestinação promovia, a Igreja Católica reagiu tanto disciplinar como dogmaticamente. O Concílio de Trento afirmou, assim, ser herética a posição dos reformadores e retomou os processos de Inquisição. No entanto, como a posição inversa que enfatizava o livre arbítrio humano em detrimento do concurso divino já havia igualmente sido condenada na época de Santo Agostinho sob o nome de pelagianismo, restou ao Concílio afirmar uma posição intermediária, em que tanto a graça como a liberdade humana concorreriam para a salvação. Em função das disputas internas ao próprio campo da Contrarreforma, não foi possível, porém, chegar a uma posição unânime sobre como precisamente se daria esta combinação, abrindo-se assim um longo capítulo da história teológica e pastoral católica em torno da questão. Dominicanos, Jesuítas e Jansenistas se digladiaram ao longo do século XVII, enfatizando teoricamente um ou outro lado da equação e definindo sacramentos e pastorais mais ou menos rigorosos no trato com os fieis (Quilliet, 2007).

A querela da graça estava, desde sua fonte inaugural, ligada à temática das paixões, já que Santo Agostinho, o Padre da Igreja cujo discurso deu forma aos termos do debate, vinculou as paixões ou à concupiscência ou à graça. Para Santo Agostinho, desde o pecado de Adão, a humanidade condenada passa a viver segundo a carne, ou seja, segundo o homem como um todo (corpo, alma e espírito), o que implica uma má espécie de amor por si mesmo (Santo Agostinho, 2000:547-550). É colocando-se no lugar de Deus, único verdadeiro Senhor, que o homem se perde na vã busca de glória, uma paixão que é propriamente espiritual ou da razão, e não corporal. Nesta paixão, o homem pode até mesmo conter os impulsos corporais, levando à aparência da virtude, mas se tratando de uma similitude apenas exterior, pois não se constitui como verdadeiro amor a Deus. Esse orgulho, porém, pode também levar com frequência a uma desordem que desfaz o controle do espírito sobre a alma inferior, abandonando o ser humano à concupiscência das paixões corporais (ibidem:551).

As paixões, no entanto, não são más em si mesmas. Estando ligadas aos movimentos da vontade, a sua avaliação é indissociável da qualidade desta, ou seja, do tipo de amor que dirige a busca humana por ser feliz (ibidem:552, 555-556). Definindo a vontade em termos afetivos, Santo Agostinho promove o primado absoluto do amor como elemento ordenador de todo discurso sobre as paixões (Talon-Hugon, 2002:56). O 
amor não se constitui como uma paixão, mas como a vontade cujos movimentos constituem as paixões e permite avaliá-las.

O homem natural, sendo incapaz de se tornar justo (já que, na medida em que atinge a (quase) virtude, ele já se perde em seu orgulho), somente pode ser liberto de toda concupiscência pela graça (Bermon, 2003:187). É a Paixão de Cristo, e mesmo as paixões de Cristo, que permitem a distinção entre as boas e as más paixões. Isto porque Cristo viveu as suas paixões como Deus que se fez homem, sofrendo como homem as paixões na alma e na carne, mas criando como Deus as próprias condições às quais se submeteu voluntariamente sem que elas despertassem nele a menor desordem e o menor pecado. É assim, pois, que Cristo salva as paixões e concede aos homens prová-las de maneira ordenada.

O amor divino que a graça desperta é uma delectatio victrix, ou seja, um deleite supremo, superior a qualquer prazer humano, pelo qual o homem decaído é atraído irresistivelmente a Deus em sua vontade de ser feliz. Se o homem permanece o sujeito da vontade, ele não é assim a sua causa primeira: "É certo que somos nós que queremos todas as vezes que nós queremos. Mas é Deus que nos faz querer o bem" (Santo Agostinho, 2002:912). Pois, nesta vontade definida em termos afetivos como amor, "Deus age pelo interior, ele toma os corações, ele move os corações, ele os desperta por desejos voluntários que ele próprio havia produzido neles" (idem, 1962:373). Na ausência da graça, "o homem [resta] abandonado a si mesmo porque ele abandonou a Deus comprazendo-se em si mesmo, e, ao não obedecer a Deus, ele não pode mais obedecer a si mesmo. E, daí, sua miséria evidente: o homem não vive mais como ele quer" (idem, 2000:590).

Conforme a esta visão de Santo Agostinho, o governo das almas passa, em primeiro lugar, pela definição de uma regra emocional e por um modo de subjetivação que busca compensar a "fraqueza" da vontade humana e direcioná-la para a renúncia de si e ao amor a Deus. Na tentativa de constituir Deus como causa primeira de uma vontade das quais os homens não deixam de ser seus sujeitos, a pastoral cristã constitui-se como a própria causa primeira dos desejos voluntários, promovendo assim um governo "emocional" cristão. Esta visão pastoral que toma a vontade humana como objeto, agindo pela persuasão sobre a vida afetiva e moral, já estava presente ainda antes de Santo Agostinho, ao menos desde o influente Règle Pastorale do Papa 
Grégoire le Grand (Senellart, 1995:27-29). Com Santo Agostinho, no entanto, dada a cisão interna do homem decaído e a sua incapacidade de governar a si mesmo, ao menos tendo por referência a regra proposta do "verdadeiro querer", é legitimado o uso da coerção, pois é preciso que os homens sofram um poder para serem capazes do bem querer. Disciplina externa que visa garantir a subjetivação da regra emocional, ela é inseparável de uma terapêutica da alma e do corpo que visa desfazer a concupiscência que converte o indivíduo em seu próprio inimigo e inimigo dos outros. Santo Agostinho apregoa um processo essencialmente ativo de severidade educativa que confere ao poder político, como órgão de repressão, um papel apostólico, fazendo do rei um ministro do sacerdócio que desfaz a aspiração dos primeiros cristãos a uma vida autônoma (ibidem:83).

Essa prática agostiniana de governo das vontades é a estratégia central que atravessa a querela da graça, que não por acaso é indissociável dos diversos tratados sobre as paixões e do primado do amor que atravessa o século XVII (Terestchenko, 2009; Talon-Hugon, 2002:58). A discussão religiosa sobre as paixões é feita sempre tendo como contraponto a graça e suas afecções, que não simplesmente se opõem, mas se sobrepõem normativamente às paixões humanas e se diferenciam delas por sua origem (a parte superior espiritual da alma e não os apetites sensíveis), objeto (amor a Deus e não à criatura) e valor. Essas afecções aparecem assim como força interior que determina a vontade, como motor de seus movimentos, como última razão sem razão, remetendo no limite ao misticismo religioso, mas igualmente se justapondo ou se confundindo com as afecções racionais que impõem seu governo sobre as paixões (Levi, 1964:204). Reversão da concepção de paixões, as afecções são ativas e moralmente boas (Auerbach, 1998; Talon-Hugon, 1999:179).

A regra emocional agostiniana se desdobrou em duas frentes de debates indissociáveis no século XVII. De um lado, a temática do puro amor, do amor desinteressado a Deus, fruto da graça divina, da anulação de si mesmo e da dissolução do sujeito em Deus. Questão fundamental da possibilidade da existência de um amor humano que não seja egoísta, que sacrifique até mesmo o interesse na própria salvação. Discussão que atravessa autores como François de Salles, Jean Pièrre-Camus, Fénélon e Boussuet. De outro lado, a questão do amor-próprio desregrado a ser moderado ou eliminado, da vaidade que se disfarça de virtude e que guia a ação egoísta do homem decaído. Discussão que se 
baseia não tanto em uma regra expressiva, mas em uma regra emocional que define o que se deve sentir, a despeito de uma manifestação exterior que pode ser idêntica na forma da virtude da caridade e da humildade. A ênfase nessa vertente pessimista foi colocada sobretudo, mas não exclusivamente, por protestantes e jansenistas, e pode ser encontrada em autores como Lutero, Jansenius, Saint-Cyran, Jean-François Senault, Blaise Pascal, La Rochefoucauld, Pierre Nicole, Jacques Esprit e outros. Sendo complementares, essas duas frentes frequentemente estão integradas nos tratados do século XVII, a despeito da ênfase para um ou outro lado.

\section{O Governo Político das Paixões}

A conversão política desse governo pastoral das paixões ocorreu desde o final do século XVI. As disputas religiosas obrigaram os Estados nacionais recém-unificados a adotarem uma religião oficial e lidarem com os dissidentes em seu próprio território e no estrangeiro. O discurso religioso sobre a graça e as paixões se convertia assim em questão de Estado. Mas o temor permanente de guerras civis e entre nações no momento mesmo em que o monarca concentrava poder fez com que muitos pensadores políticos pensassem em estratégias pacificadoras. Nesse contexto, a releitura cristianizada da filosofia estoica foi especialmente operacional, pois, além de inicialmente buscar uma versão teologicamente neutra, ainda promovia uma moderação das paixões (inclusive confessionais) dos súditos e fiéis e oferecia ferramentas de manipulação aos príncipes, constituindo uma vertente propriamente política de governo da vida "emocional" em claro paralelo com o modelo do governo divino.

Juste Lipse, principal apresentador e sistematizador da doutrina neoestoica no século XVI, foi também autor de um dos mais influentes tratados políticos do período, sendo lido pelos dois lados da cristandade ocidental dividida. Lipse claramente articulou uma autodisciplina neoestoica com um poder "emocional" político. Por um lado, Lipse (2010) sugeria um cuidado de si que tinha por ideal a constância e que, ao mesmo tempo que propunha uma autonomia interior que buscava a submissão das paixões (concebidas como derivadas de falsas opiniões estimuladas pela imaginação) à reta razão, propunha externamente uma submissão (inclusive religiosa, independentemente da crença interna) aos governantes. Inversamente, do ponto de vista do Príncipe, Lipse (1994) converteu o gênero moralizante do Espelho dos 
Príncipes em um tratado de habilidade de governo do povo e dos adversários. Pensando o povo como guiado principalmente por suas paixões, Lipse reuniu as figuras antropológicas pessimistas do volúvel estoico (contrário do sábio), do homem decaído agostiniano (contrário do eleito) e do político indócil de Maquiavel (contrário do cidadão da República ideal de Platão). Lidando com homens passionais, ao Príncipe caberia uma arte especial de governo afetivo, de modo a guiar as opiniões dos súditos e garantir a paz e a união do Estado, precondições para sua potência política. As virtudes e os vícios do Príncipe, deste modo, diziam respeito não apenas à moral cristã, mas sobretudo à habilidade (ou à falta dela) de governar afetivamente os súditos. Para Lipse, virtude era "uma elogiável afecção do rei ou com relação ao rei, útil ao Estado" (ibidem:33-35), enquanto vício se tratava da "má e danosa afecção que se tem do rei ou contra o rei e seu Estado" (ibidem:57).

Esta versão de governo político das paixões marcou amplamente a visão da Razão de Estado nascente. Na França, por exemplo, Pierre Charron (1986) se baseou explicitamente no modelo político de Lipse e retomou sua discussão sobre a virtude da prudência mista, relativa ao bem governar, para oferecer uma versão que foi adotada pelos estatistas em toda primeira metade do século XVII (Lazzeri, 1992). Além disso, Charron acrescentou às técnicas neoestoicas de governo afetivo um tratado sobre as paixões, de modo a dar a conhecer melhor o povo, apresentado igualmente como "volúvel, inconstante, amotinado, tagarela, amante da vaidade e da novidade, orgulhoso e insuportável na prosperidade, covarde e abatido na adversidade" (Charron, 1986:551). Mas talvez tenha sido Jean-François Senault (1987) quem ofereceu a versão mais acabada deste tipo de tratado. Realizando uma releitura católica do pensamento e das práticas estoicas, vinculou a própria possibilidade da sabedoria ao concurso divino, reintroduzindo assim em outro nível a querela da graça. Nesta versão, a razão seria impotente diante das paixões concupiscentes sem o apoio decisivo do amor divino, embora tampouco a graça recebida dispensasse o esforço humano pelas boas obras. Tendo as afecções da graça como horizonte, Senault preconizava um uso mais do que a erradicação das paixões, buscando a moderação ou a manipulação por meio de uma terapêutica da alma e do corpo. As técnicas propostas partiam assim tanto de uma profilaxia e terapêutica estoicas da alma quanto da medicina galênica, que buscava, por meio de dietética e de gyminastica, um equilíbrio dos quatro humores. 
A duplicidade corpo-alma era indissociável da maneira como se pensava a fonte das paixões na época. A maior parte dos tratados do século XVII adotava uma definição tomista das paixões que as tomava como movimentos da parte sensitiva da alma para se aproximar do bem e se distanciar do mal (Talon-Hugon, 2002:8). As paixões eram localizadas, então, nessa parte da alma irracional ligada aos apetites sensíveis que sofre com as transformações do corpo, transformações que a própria alma pode desencadear e depois ressentir. Situadas não em uma alma isolada, mas em uma alma que está inserida em um corpo, as paixões atingem acidentalmente a alma, ou seja, não na sua essência imutável, mas somente naquilo em que está imbricada no composto que é o homem. Devido a esta imbricação corpo-alma, as paixões podem ser alvo de uma terapêutica dirigida para um ou outro lado.

O uso das paixões, para Senault, não era, no entanto, prerrogativa exclusiva de médicos ou religiosos, mas também de políticos. Para o autor, a moral podia ser compreendida como um uso das paixões que "instrui os políticos e lhes ensina a governar os Estados governando suas paixões" (Senault, 1987:27). Na dedicatória feita ao Cardeal Richelieu, após afirmar que "é preciso regrar as próprias afecções antes de conduzir os homens" (ibidem:2), Senault remete ao que ele considera mais adiante ser "a maior obra que pode empreender um homem de Estado" (ibidem:137): ler as intenções no fundo dos corações e desvelar os pensamentos secretos e dissimulados (ibidem: 7 e 138). Sendo o coração dos homens um abismo, apenas há frágeis indícios para adivinhar o que ele esconde. Para Senault, é o conhecimento das paixões que permite desvelar esses recônditos secretos, "pois elas escapam contra nossa vontade, elas nos traem por sua presteza e volatilidade" (ibidem:138). E é assim que aquele que não aprendeu a governá-las e preveni-las acaba por se entregar aos inimigos e a permitir que eles o governem (ibidem:138).

O regramento justo das próprias paixões é complementado, assim, pelo uso prudente das paixões alheias (ibidem:7). Conhecendo as paixões humanas melhor do que os sujeitos conhecem a si mesmos, Richelieu teria ganhado os súditos e adversários por suas paixões, servindo-se delas como "cadeias para prendê-los e detê-los". Acorrentados pelo coração, seria possível os conduzir segundo os desejos e as necessidades do governante, que imitaria no Estado a condução de Deus no mundo: primeiro, acomodando-se às inclinações de suas criaturas e agindo tanto com afabilidade como com força; segundo, fazendo-os 
obedecer sem que eles conheçam os mistérios de quem governa, combinando "a necessidade com a vontade, e o bem do Estado com a inclinação dos particulares" (ibidem:9).

Em seu tratado, Senault sugere uma estratégia abaixo da Majestade da Religião, de modo a inicialmente se acomodar à fraqueza passional e a persuadir de acordo com considerações humanas, tomando as paixões por seus próprios interesses e se servindo de suas inclinações para suavizar seu furor e encaminhar os homens para a virtude e a caridade ( $i b i$ dem:32). Mas, para tanto, inaugura uma forma de conhecimento das paixões que busca desvendar, sob toda dissimulação e falsas aparências, as verdadeiras afecções que comandam o coração e guiam a conduta humana. Partindo da versão jansenista do homem decaído, é o amor próprio que se apresenta para Senault e para os moralistas da segunda metade do século como o motor que sempre está por trás das ações, mesmo das virtuosas, humildes e caridosas. Como afirmava La Rochefoucauld (1992:179): “O amor próprio é o amor de si mesmo e de todas as coisas por $\mathrm{si}^{\prime \prime}$.

Na França de meados de século, esse conhecimento do amor-próprio como técnica de deciframento era operacional tanto no contexto externo quanto interno. Externamente, permitia denunciar a hipocrisia da grande rival na Guerra dos Trinta Anos, a Espanha, que instrumentalizava a defesa ortodoxa da religião católica e utilizava justificativas morais para recobrir atos ilegítimos - o que justificaria a aliança francesa com a Suécia protestante em nome da defesa do próprio cristianismo contra o reinado Habsburgo (Thuau, 2000:367 e 377). Internamente, permitia uma decifração das posições e das complexas relações de força durante os vários conflitos e intrigas da Fronde, quando nobres, clérigos, oficiais, burguesia e uma parte do povo se levantaram contra o excesso de impostos cobrados para sustentar as guerras externas e contra a centralização do poder monárquico absolutista na mão de um primeiro ministro (Richelieu e, depois, Mazarin).

É este entrecruzamento, mais uma vez, entre governo político e religioso que faz com que "não haja época na história do pensamento ocidental que tenha denunciado de maneira mais radical e sistemática o amor próprio do que o século XVII" (Terestchenko, 2000:19). Os moralistas, no entanto, para além da questão da intenção moral, depararam-se com a questão da ação e de seus resultados. Trata-se de uma questão central já que o desvelamento do amor-próprio como princípio da ação 
remete ao perigo que tal motivação coloca para a existência e estabilidade dos laços sociais. Concebida como uma força ativa que não pode ser erradicada, ainda que reprimível por sanções, essa maneira de sentir oposta às prescrições da religião e da moral constituía-se como ameaça potencial de conflito.

A resposta teórico-política a este desafio foi dupla. Em ambos os casos, ainda que partindo de uma problemática francesa, a solução teve forte impacto no país vizinho, a Inglaterra, que passava por guerras religiosas articuladas à disputa entre Rei e Parlamento pela soberania. De fato, a Inglaterra já possuía sua própria leitura dos neoestoicos e sua própria tradição protestante de naturalização e governo das paixões, cujos precursores foram Francis Bacon (2000 [1625]) e Thomas Wright (1986). A transferência para o contexto inglês de ideias surgidas na França só foi possível dada a grande e não casual afinidade entre a concepção antropológica pessimista de jansenistas e puritanos, especialmente no que se refere à determinação e impotência da vontade humana diante da concupiscência, sendo a ação guiada pelo amor-próprio no caso de ausência da graça. Esse deslocamento contextual, no entanto, produziu um escândalo moral ao mesmo tempo em que teoricamente ofereceu formas opostas de saída política para as duas revoluções inglesas do século XVII.

No primeiro caso, procurou-se constituir uma ciência das paixões de modo a se deduzir um modelo político a partir dela. As paixões tornavam-se com Descartes e, depois, com Hobbes e Spinoza objetos de conhecimento das ciências da natureza, sendo o corpo humano visto como um corpo entre os demais corpos e suas leis vitais submetidas às regras mais gerais das leis universais ou físicas. O sucesso da revolução galileana, com sua ciência rigorosa dos corpos materiais, criou a tentação de estender essa ciência sobre outros objetos, produzindo efeitos na teoria das paixões. Surgiu, assim, a exigência de se constituir uma física ou uma geometria das paixões, convertendo-as em forças que operam no plano moral e definem condutas. As paixões convertem-se, assim, nos motores da ação humana (Moreau, 2003:5-7; Hirschman, 1980:16-18).

Hobbes (1997 [1651]) partiu dessa geometria patética para compor um modelo político que respondesse à urgência da situação inglesa na primeira revolução. O soberano inglês, chefe simultaneamente religioso e do Estado desde Henrique VIII, não podia se apoiar nem no catolicis- 
mo (o que implicava retroceder politicamente à intervenção externa do Papado), tampouco nos puritanos (cuja radicalidade faria contestar uma religião de Estado e o próprio Estado). Afirmando uma religião de Estado independente, o rei descontentava ambos os lados e se via estrangeiro em seu próprio país, ao passo que a Câmara dos Comuns se consolidava como representante dos ingleses e desafiava a soberania com a constituição de um corpo político autônomo.

A fundação deste corpo político, porém, estando vinculada às diferentes confissões, conduzia à sua própria dissolução em guerra religiosa. Hobbes, entrevendo no reforço do poder soberano a única saída, procurou desvincular sua legitimidade da religião. Rompeu assim com a doutrina aristotélica e tomista que se questionava pelo telos da política, o que remetia ao supremo bem que, nos termos religiosos da época, repunha a querela em torno dos caminhos da salvação. Hobbes se afastou das opiniões religiosas que promoviam o mal por excelência: a ruína da sociedade civil e a morte de seus cidadãos. E partiu da fuga desse mal absoluto para fundar sua arte política. A paixão do medo da morte, conhecida por experiência por todos, é tomada assim como fundamento da ação humana e como ponto de partida para uma organização política invulnerável aos conflitos de opinião. Medo que está presente, segundo Hobbes, não apenas em momentos de guerra civil, mas igualmente na vida ordinária, sendo a guerra de todos contra todos a condição natural da humanidade. Guiados pelo amor-próprio, se não houver o temor do poder público que o contenha, a rivalidade entre os homens descaminha para a usurpação, luta e assassinatos.

Ao contrário dos moralistas franceses, no entanto, Hobbes não vê as paixões humanas e a violência natural como pecados, pois apenas após a promulgação das leis as noções morais de bem e mal podem se constituir. É assim que a arte política funda um novo bem (ou um mal menor), propriamente político. Os homens são impulsionados por sua própria paixão do medo de uma morte violenta no estado de natureza a resolver pela razão os meios de sua conservação. Estabelecem, assim, entre si um contrato pelo qual renunciam ao seu direito natural, transferindo para o soberano o direito ilimitado de violência pelo qual quem infringir o pacto será castigado. É deste modo, pois, que Hobbes deduz a necessidade do poder soberano absoluto a partir de uma física das paixões. E, ao fazer isso, desloca a finalidade do poder passional: da salvação religiosa para a segurança e o bem-estar material terrenos (Hobbes, 1997; Manent, 1987:51-88). 
A outra solução pensada pelos moralistas franceses da segunda metade do século XVII conferia um resultado paradoxal aos efeitos do amor-próprio: não sendo curado a não ser pela graça divina, seus efeitos negativos podem, no entanto, ser compensados pela ação de seu próprio veneno. Metáfora da medicina galênica, mais uma vez, que, com suas bases geométricas pitagóricas, promove o ideal da harmonia pelo equilíbrio entre partes que se opõem e se combinam (Klibansly, Panofsky e Saxl, 1989:32-33) e permite a emergência de uma saída pelo contrabalanceamento das paixões, como enfatiza Hirschman em seu texto clássico (1980). Enfatiza-se aqui a submissão da razão às forças passionais e a conversão do amor-próprio da busca por glória em busca por conforto material e segurança, constituindo efeitos que se assemelham aos da própria caridade, como a pacificação e a melhoria do bem-estar (Nicole, 1999). Tal saída promove um deslocamento do objeto amoroso da esfera religiosa e da honra para o plano econômico da industriosidade e do comércio. Neste caso, o interesse esclarecido é mesmo prescrito, pois, como explica Pierre Nicole (1999:415), “há, sem dúvida, mais desregramento e desordem em não servir a Deus quando alguém se priva ao mesmo tempo daquilo que o próprio interesse o conduz a desejar e a buscar para a sua própria vantagem".

Tal é a saída que Bernard Mandeville $(1934,1996)$ importaria para o contexto inglês pós-Revolução Gloriosa, ao expor em sua fábula a ideia de que vícios privados podem acarretar benefícios públicos. Com tal medida, Mandeville, que não por acaso era médico e leitor dos moralistas franceses, oferecia uma saída que, mesmo contrariando as virtudes cristãs ao inverter a regra emocional central do século XVII, permitia pensar a partir do amor-próprio a constituição de um corpo social autônomo e pacificado sem a necessidade de um soberano absolutista, vinculando assim o poder "emocional" a uma Razão de Estado liberal indissociável da vitória parlamentar. E consolidava o mesmo deslocamento de finalidade ou telos do poder "emocional" já proposto por Hobbes: da salvação celeste para o bem-estar material, abrindo caminho para uma nova visão de felicidade mundana.

Essa mesma discussão foi introduzida na Escócia, cuja anexação à Inglaterra em 1707 se deu principalmente pela bem-sucedida via comercial, deslocando tensões religiosas e políticas que opunham os países. Foi neste contexto pacificador, mas que igualmente colocava o desafio de como um país mais pobre poderia superar as desvantagens comerciais com um país mais rico, que emergiu a Economia Política 
nos textos que ficaram conhecidos como "iluminismo escocês" (Waszek, 2003:15-20). A Economia Política dizia respeito, assim, tanto ao problema da constituição de um corpo social autônomo pacificado (escocês em relação à soberania inglesa ou britânico de modo geral) quanto ao do progresso material da sociedade, tendo sempre como fundamento a regra "emocional" do amor-próprio e a regra expressiva da ação interessada racionalmente calculada.

\section{A EMERGÊNCIA DOS SENTIMENTOS MORAIS}

O escândalo causado por concepções de política e sociedade não religiosas baseadas em paixões egoístas não ficou sem reação. Em oposição a Hobbes e Mandeville, a concepção de sentimentos morais emergiu no seio da mesma Razão de Estado liberal britânica, especialmente escocesa. Tinha, assim, por finalidade limitar o poder soberano a partir de uma normatividade "emocional" não religiosa que constituísse um corpo social autônomo e a promessa de felicidade terrestre, mas resgatando de maneira imanente a regra emocional cristã do amor. Deste modo, precisavam oferecer uma antropologia naturalizada da caridade, limitando a ideia de que os laços de puro interesse é que uniam os indivíduos em sociedade. Visando a naturalização política, adotaram-se os mesmos pressupostos antropológicos daqueles que enfatizavam os laços imanentes de interesse, como a ideia fundamental da impotência da razão diante de paixões que influenciam decisivamente a vontade e determinam as condutas. Naturalização antropológica que se completava com a transformação proposta por Locke concernindo a relação entre mente e corpo. Procurando "esvaziar" a mente de ideias inatas, de modo a escapar da querela da graça (e das consequentes lutas religiosas) e abrir os homens ao governo de seus semelhantes, Locke (1987 [1689]; Armstrong e Tennenhouse, 2006) vinculou as ideias às sensações, ao mesmo tempo em que se desfez da concepção de corpo galena, cuja leitura cristã associava a desarmonia humoral ao pecado original e à necessidade de remissão divina. As paixões e os sentimentos adquiriram assim uma nova fonte baseada em um corpo sensorial de dor e prazer e na sua articulação no âmbito da mente com as faculdades da razão, memória e imaginação.

Nos termos desta antropologia, a recuperação da regra cristã foi feita via a renovação da temática medieval da consciência moral em termos de forças "emocionais", de modo que o amor benevolente pudesse ser 
apresentado como princípio ativo da ação individual ao lado do interesse egoísta.

A temática da consciência moral, presente desde a Antiguidade nos textos de Demócrates, nos quais significa a percepção que se tem das más ações que se realizam, e que engendra o temor de castigos no além, tem por vezes seu sentido ampliado na tradição greco-latina, designando, além da consciência que percebe o mal e o julga, também aquela que apreende o bem e a alegria que o acompanha. Nas epístolas de São Paulo, a consciência moral designa não apenas a consciência que segue os nossos atos e os avalia, mas também a consciência que preside a conduta das ações futuras, pois discernir o bem e o mal permite, com efeito, julgar as ações passadas e conduzir as futuras. A consciência moral refere-se, portanto, mais a uma questão de psicologia moral, pela qual se discute como se dá a percepção das diferenciações morais, do que a uma ética normativa. No pensamento medieval, a consciência moral perdeu a sua autonomia enquanto faculdade da alma e passou a ser considerada como disposição da razão. Precisamente, a tradição escolástica é "cognitivista e racionalista: trata-se de conhecer o bem e o mal, o que dita a lei natural, e esse conhecimento é a contrapartida dos princípios teóricos" (Baertschi, 2003:560). Assim, a temática da consciência moral para os medievais, mesmo dizendo respeito a esclarecimentos quanto à psicologia moral, não deixou de articular seus fenômenos aos imperativos da teologia e da religião, respaldando em Deus o seu caráter de obrigação.

Entre as obrigações cristãs, a benevolência se apresenta como uma das mais valorizadas. Benevolência "é o ato de tender para o que, para o outro, é o bem, sem que esse bem coincida necessariamente com o que o autor considera como tal para a sua própria vida; ela consiste, segundo a fórmula leibniziana, em alegrar-se com a felicidade do próximo" (Cléro, 2003, vol. II:585). O bem do próximo pode ser compreendido como sua felicidade ou como o desenvolvimento de sua personalidade, o que não necessariamente é a mesma coisa. $\mathrm{O}$ amor benevolente, para os autores cristãos da Idade Média (Tomás de Aquino, Pierre d'Ailly, Biel) e para Leibniz, é diferente do amor concupiscentiae, que pertence à ordem do desejo amoroso e prefere servir-se do outro a servir o bem e os objetivos desse outro.

\section{Senso Moral}

Em termos teóricos, o conceito de senso moral surgiu como uma resposta à denúncia de que a benevolência, no fundo, se baseava nas paixões 
privadas, tal como sugerido por Mandeville (1934 e 1996). A teoria do senso moral buscava, assim, resgatar a benevolência da sua redução aos interesses individuais e restaurar a veracidade de sua existência. Autores como Lord Shaftesbury (1996) e Francis Hutcheson (1996) procuraram conferir um lugar natural para a consciência moral e para a tendência à benevolência, com tudo o que esta implica em termos de preocupações altruístas e com o bem comum. O conceito de senso moral se opôs, em outra frente, à moral racionalista, que encontrava seu fundamento, justificativa e princípio nas ideias inatas e na verdade da Lei. O senso moral era, então, o conceito pelo qual a diferenciação operada pela consciência moral se dava por sensações, e a benevolência foi convertida em tendência natural expressa em forma de sentimento que atuava como princípio ativo da ação, podendo agir como uma força em meio ao mundo das paixões. Afinal, se uma paixão só pode sofrer o efeito de outra paixão, a moral, para interferir no curso das ações humanas, precisava ser pensada por analogia a essa força motriz das condutas, e não como uma verdade ou razão impotente. A percepção de bem do senso moral, assim, não seria derivada de educação, conhecimento ou de quaisquer ideias inatas (Hutcheson, 1996:120). As suas percepções são imediatas, ou seja, elas nos ocorrem "independentemente de nossa vontade" (Hutcheson, 1996:116), e se expressam por meio de forças afetivas, semelhantes às paixões, de aprovação e condenação. No entanto, essas "paixões sociais" não eram designadas, na maioria das vezes, pelo termo paixão, mas, sobretudo, pelo termo sentimento, a fim de enfatizar a oposição de um julgamento moral ao caráter autorreferido e egoísta que marcara a primeira temática. Ao amorpróprio e a uma predileção pela vantagem pessoal, os sentimentos contrapunham a benevolência e o bem comum. Emergiu daí a temática dos sentimentos morais.

Ao mesmo tempo, porém, em que a moral era entendida como uma força entre forças na mecânica geral das paixões, era preciso também que os sentimentos se vinculassem às sensações de dor e prazer que estavam no fundamento das paixões, mesmo sem consentir na autorreferência interessada. A solução encontrada para essa questão é que definiu a especificidade do conceito de senso moral na temática geral dos sentimentos morais. De fato, o senso moral e os sentimentos dele derivados, para serem considerados naturais e ao mesmo tempo escaparem de sua redução ao interesse, precisariam estabelecer uma nova relação com as sensações de prazer e dor. Assim, ao invés das sensações externas experimentadas pelos cinco sentidos, o senso moral referia-se 


\section{Daniel Pereira Andrade}

às "sensações internas", a um poder interno de percepção pelo qual a mente dos seres racionais receberia os reflexos das ações e afetos de outras pessoas ou de si próprios. Segundo Shaftesbury (1996:17),

numa criatura capaz de formar noções gerais de coisas, os objetos de afeto não são apenas os seres exteriores que se lhes apresentam aos sentidos, mas também as próprias ações e aqueles afetos, tais como a compaixão, a gentileza, a gratidão e seus contrários, trazidos à mente por reflexão. Assim, mediante esse sentido refletido, surgiu ali outra espécie de afeto em relação àqueles já sentidos e que eram, então, o motivo de um novo prazer ou desgosto.

Tratava-se de um senso ou sentido (sense), ou seja, de uma "determinação de nossas mentes para receber ideias independentemente da nossa vontade e ter percepções de prazer e dor" (Hutcheson, 1996:159). A percepção de aprovação ou desaprovação do senso moral seria um sentido passivo, necessário, imediato e espontâneo, ou seja, não volitivo, não havendo nenhuma volta implícita ou explícita do sujeito sobre si mesmo, e, portanto, não poderia ser explicado em termos de amorpróprio ou interesse privado (Hutcheson, 1996:122-133; Shaftesbury, 1996:18). As percepções do senso moral não se confundiam com as sensações externas, constituindo outra classe de percepções sensíveis e vinculada a uma ideia de bem moral que denota "a nossa ideia de alguma qualidade apreendida em ações, a qual obtém aprovação acompanhada do desejo de felicidade do agente", tratando-se "de um princípio inteiramente diferente de ação do que aquele oriundo do amor de si ou do desejo de bem pessoal" (Hutcheson, 1996:111 e 114). Esse princípio que estava no fundamento das avaliações do senso moral seria a benevolência (Hutcheson, 1996:114-115). Os afetos benevolentes são uma disposição natural não reflexiva presente igualmente nos homens e em outros animais. Mas é a benevolência natural definida como critério do senso moral que permite aos homens um prazer de segunda ordem, na medida em que ele imediatamente julga e aprova os sentimentos benevolentes que o próprio agente experimenta ou que ele representa para si na reflexão sobre a ação de outros (Hutcheson, 1996:143).

Tornava-se possível, nesse sentido, a existência de outro tipo de sensações, de forças afetivas e de princípio de ação que não se reduziam ao interesse egoísta. A naturalização da benevolência e a existência do senso moral, com suas percepções internas não volitivas exclusivamente morais, deram origem a sentimentos cujo princípio escapava ao 
amor de si. Não seria o caso, contudo, de negar a existência das sensações corporais externas e das paixões egoístas, nem de negar sua utilidade, mas de criar uma base sensível e sentimentos que existissem independentemente das forças motrizes passionais e que interagissem com elas, influenciando no jogo que definia o sentido das condutas e determinava os conteúdos dos laços sociais. Ações altruístas e laços de solidariedade não apenas apareciam ao lado e disputando com as ações egoístas e os laços de interesse, mas se impunham a eles, na medida em que os prazeres morais seriam, além de mais nobres, de uma classe superior de satisfação que a dos prazeres naturais. A superioridade dos prazeres morais, contudo, não significava uma recusa completa dos interesses pessoais, na medida em que os afetos autorreferidos eram inteiramente necessários na manutenção da existência individual e, portanto, na própria consecução do bem comum. Desse modo, mais do que uma disputa sem trégua por meio da qual um dos afetos procuraria eliminar o outro, tratava-se de um predomínio dos sentimentos morais sobre as paixões egoístas, por meio do qual estas últimas seriam preservadas e moderadas pelos primeiros, equilibrando harmoniosamente a parte e o todo, o indivíduo e a espécie ou a sociedade.

A obtenção desse equilíbrio passaria pela intensidade dos sentimentos morais, que seriam tanto mais fortes quanto maior fosse a proximidade experimentada com o objeto de afeição. Assim, ainda que a benevolência experimentada no amor por toda a humanidade fosse moralmente superior, ela seria genérica demais para se impor aos interesses egoístas. Seria preciso, portanto, o amor a um objeto mais próximo, que, ainda que fosse mais restritivo, apresentaria intensidade maior. Aparece, assim, como alternativa mais indicada a afeição a um grupo social próximo de pertencimento, como patriotismo, amizade e amor parental (Hutcheson, 1996:136-137).

Considerando a ascendência harmoniosa dos sentimentos morais sobre as paixões, a teoria do senso moral contradizia a consideração do comportamento normal, descrito pela nascente Economia Política pelo princípio do cálculo de interesse. Ao cálculo de interesse, os teóricos do senso moral opunham um cálculo moral que permitia orientar a escolha entre várias ações propostas, ou decidir qual delas possuía a maior excelência moral, baseando-se em variáveis como a quantidade de bem e mal causada, o número de pessoas atingidas, e a proporção 
entre bem e mal das consequências diretas e da probabilidade das consequências indiretas da ação.

\section{Simpatia}

Por meio do senso moral, a regra emocional cristã do amor benevolente era teoricamente reintroduzida, retornando no interior mesmo de uma governamentalidade liberal, partilhando da mesma concepção antropológica e operando dentro de sua lógica (referência ao corpo concebido em termos de sensações de dor e prazer, às forças afetivas como determinantes das condutas e ao cálculo racional). Mas permanecia o problema teórico de afirmar a existência de um prazer, ainda que de tipo moral, que não remetesse inevitavelmente ao amor de si e ao interesse. E restava ainda o problema prático de como promover um tipo de amor que implica uma renúncia de si sem recorrer à pastoral cristã ou diretamente ao poder soberano. Como o conceito de senso moral dizia respeito somente a um sentido imediato, ele era omisso na formulação de uma prática de si ou de uma forma de governo que o pudesse constituir subjetivamente sem anular a autonomia do corpo social, embora já começasse a apontar o caminho dos grupos de pertencimento.

Diante dessas questões, um segundo conceito foi mobilizado em meados do século XVIII como uma fonte de sentimentos morais alternativa ao senso moral e à benevolência inata no âmbito da mesma concepção antropológica de homem passional: a simpatia. A simpatia substituía um sentido interno inato ao indivíduo por um princípio de comunicação das paixões por intermédio do qual se teria acesso internamente ao que outros sentiam. Tratava-se de um princípio que se situava no interior da própria teoria geométrica e física das paixões, através de uma mecânica de transferência dos afetos. A simpatia, assim, embora também propusesse uma reintrodução da regra do amor cristão por meio dos sentimentos morais, se enquadrava perfeitamente na teoria das paixões, harmonizando-se com suas leis geométricas e mecânicas sem precisar introduzir novos princípios autônomos na mente como fontes de sensações, afetos e ações. Ela não excluía a benevolência, mas tinha uma extensão mais ampla que esta, já que, enquanto a benevolência comportava exclusivamente o deleite com a felicidade do próximo e o entristecimento com sua infelicidade, a simpatia podia, além disso, reproduzir no espectador sentimentos contrários daqueles que ele era testemunha (Cléro, 2003:586). 
A simpatia diz respeito a um duplo procedimento: primeiro e fundamentalmente, a uma comunicação das paixões, por meio da qual os homens podem ter acesso em seu íntimo aos afetos experimentados por outra pessoa; segundo, através dessa comunicação, a uma moderação das paixões egoístas pela prescrição dos sentimentos morais. Essas duas operações da simpatia produzem uma sociabilidade que transcende o interesse, tornando possível a vida solidária em sociedade mesmo no interior de um mundo governado pelas paixões. De fato, para autores como David Hume (2001 [1738]) e Adam Smith (1999), tal mobilidade das paixões permite uma descrição do mundo social e moral, fundando a sociedade sobre essa base comunicativa (Mullan, 1988:24).

A primeira e principal operação da simpatia, portanto, é a comunicação das paixões, a qual pode se dar, segundo diferentes formulações do conceito, de modo imediato ou mediato. No primeiro caso, como argumenta Hume, a mente do espectador, ao deparar-se ou com os efeitos das paixões, manifestos nas expressões do corpo e da linguagem, ou com suas causas, percebidas em situações cujos resultados a mente pode inferir, permite a formulação de uma ideia sobre o que outra pessoa sente. Como para Hume a ideia não difere da impressão, a não ser no grau de vivacidade e força, ela pode transmitir o afeto da pessoa primeiramente concernida. Essa comunicação é garantida pelo fato de que há uma semelhança fundamental entre as criaturas humanas, sendo "as mentes de todos os homens similares em seus sentimentos [feelings] e operações" (Hume, 2001:615). Para que essa comunicação seja completa, de modo que o afeto transmitido seja avivado a ponto de se assemelhar crescentemente em intensidade à impressão original que a despertou, outras similaridades além daquela da natureza humana devem estar presentes, como nas maneiras, caráter, país ou linguagem, e também na contiguidade, consanguinidade e convivência.

No segundo caso, em que a comunicação da paixão se dá de forma mediata, Adam Smith argumenta que o acesso às "emoções" dos outros ocorre não por uma transferência direta, mas por meio da imaginação que nos permite nos colocar na situação da pessoa concernida. Nas suas palavras: "Como não temos experiência imediata do que outros homens sentem, somente podemos formar uma ideia da maneira como são afetados se imaginarmos o que nós mesmos sentiríamos numa situação semelhante" (Smith, 1999:5-6). A simpatia remete, então, a uma relação com os outros mediada por uma relação consigo mesmo, na 
qual a solidariedade que sentimos a respeito de qualquer paixão alheia passa pela nossa ação imaginária de nos atribuirmos o seu caso. Para Smith, "a simpatia não surge tanto de contemplar a paixão, como da situação que a provoca" (ibidem:9). Além disso, segundo Smith, a simpatia provoca um tipo de prazer e dor específicos: "nada nos agrada mais do que observar em outros homens uma solidariedade com todas as 'emoções' de nosso próprio peito; e nada nos choca mais do que a aparência do contrário" (ibidem:11). É a reciprocidade dos sentimentos alheios, pois, que nos dá satisfação neste caso, não qualquer consideração egoísta sobre as vantagens pessoais dela derivadas. Esse prazer é suficiente para reavivar a alegria sentida ou aliviar a dor sofrida. $\mathrm{O}$ prazer derivado da reciprocidade dos sentimentos não diz respeito apenas àquele concernido principalmente pela paixão, mas também ao espectador. Também este sente satisfação quando é capaz de compartilhar um afeto e fica do mesmo modo magoado quando é incapaz disso.

Desse modo, a simpatia, enquanto operação de comunicação das paixões, acabou, ao mesmo tempo, por mantê-las como princípio ativo das condutas, mas também por criar as condições para o surgimento de afetos passivos, sendo esses justamente aqueles recebidos pelo "contágio", para utilizar a expressão de Hume (2001:642). O termo mais utilizado para designar esses afetos passivos derivados da transmissão das paixões foi, mais uma vez, sentimento (sentiment), embora outros sinônimos também pudessem ser utilizados, como feeling, afeto (affection), emoção (emotion) e até mesmo paixão (passion), na medida em que é esta mesma que é transfundida da pessoa primeiramente concernida ao espectador (Mullan, 1988:24). Apareceu, assim, nos textos de David Hume e Adam Smith, um intercâmbio dos termos paixão e sentimento como sinônimos, ainda que o primeiro designasse prioritariamente os afetos que são ativos e derivados da natureza humana, e o segundo aqueles que são passivos e derivados da simpatia. A passividade dos sentimentos, que já havia sido insinuada no conceito de senso moral, torna-se, com o conceito de simpatia, uma nova característica distintiva perante as paixões.

Essa passividade dos sentimentos era justamente o que permitia que o outro se fizesse presente enquanto afeto no próprio sujeito, moderando assim as paixões pelos sentimentos morais. Essa segunda operação da simpatia constituiu uma normatividade das maneiras de sentir ao moderar os impulsos egoístas e estimular os altruístas. Segundo Smith, por exemplo, a simpatia determina dois diferentes esforços que 
constituem dois grupos distintos de virtudes. No primeiro caso, o esforço do espectador para fazer suas as paixões da pessoa diretamente afetada promove as virtudes ternas, gentis, amáveis, as virtudes da franca condescendência e indulgente humanidade. O esforço do sofredor para rebaixar suas "emoções" até o limite em que o espectador é capaz de acompanhá-las estimula as virtudes da abnegação, do autocontrole, do domínio das paixões que submete todos os movimentos de nossa natureza àquilo que exigem nossa dignidade e honra e a propriedade de nossa conduta. Ao restringir os afetos egoístas e cultivar os benevolentes, Adam Smith observa a proximidade da simpatia com a moral cristã: "assim como amar a nosso próximo do mesmo modo que amamos a nós mesmos constitui a grande lei do Cristianismo, também é o grande preceito da natureza amarmos a nós mesmos apenas como amamos ao nosso próximo, ou, o que é o mesmo, como o nosso próximo é capaz de nos amar" (Smith, 1999:26).

O conceito de simpatia de Adam Smith, deste modo, tornava-se operacional, pois, além de oferecer uma solução teórica ao conceito de senso moral, ainda introduzia uma técnica de subjetivação da regra "emocional" do amor benevolente e de moderação do amor-próprio baseada em uma prática de si (imaginação de se colocar no lugar do outro e esforço para se adequar ao sentimento alheio), descartando o imediatismo. Mas este mesmo conceito, no entanto, encontrava dificuldade em resolver a questão da coesão social em uma sociedade dividida em facções. O contágio e o compartilhamento das paixões podiam criar um entusiasmo excessivo que derrubava as contenções apropriadas, promovia a irracionalidade das massas e as cisões no interior da própria sociedade, convertendo sua unidade em conflito e promovendo a instabilidade política. A simpatia mantinha as pessoas juntas e supria a necessidade humana de sociabilidade, mas não necessariamente da maneira desejável para a coesão social (Shaftesbury, 1964:13-14 e 75-76; Mullan, 1988:26-29).

\section{O Amor Conjugal como Fonte de Afetividade Social}

Adam Smith propunha, assim, como forma de subjetivação do amor benevolente um cuidado de si autônomo que se aproximava do autocontrole estoico, mas fazendo um novo uso da imaginação: ao invés de tomá-la como estimuladora de falsas opiniões ou de apetites sensíveis, a imaginação, ao permitir se colocar no lugar do outro, promovia sentimentos desinteressados que moderavam o amor-próprio. Ao lado des- 
te cuidado de si moderador, alguns contemporâneos de Smith sugeriram como técnica de subjetivação uma forma de governo igualmente inerente ao corpo social autônomo e não religiosa. O caminho sugerido foi o da identificação do amor conjugal com o amor benevolente, constituindo uma espécie de governo feminino sobre os homens que se realizaria como uma arte de "gentileza e atração" (Mackenzie, 1979, I:187). Essa arte, ao mesmo tempo, impunha um novo papel e novas virtudes femininas na sociedade.

Em meados do século XVIII, o amor conjugal passou a ser visto como um ímpeto de civilidade, inclinando a mente masculina a ultrapassar o interesse particular. Antes visto como uma paixão desregrada, egoísta, efeminadora, causa de distração dos imperativos de autocontrole estoico, uma ameaça aos laços sociais de parentesco aristocrático e amizade masculina, o amor conjugal passa a ser concebido como inextricavelmente ligado à afeição social em geral. Para além da atração sexual, as aflições ternas que ele proporciona, ao tocar o coração, contribuem para o refinamento do gosto e das maneiras e para uma sociedade mais humana, compassiva e educada. $\mathrm{O}$ amor teria inclusive a possibilidade de abrandar o estoicismo, contribuindo para a benevolência masculina. Como afirma John Dwyer em seu estudo (1998:103):

Era esperado de o amor sentimental desempenhar um papel maior no cultivo daquelas paixões sociais e de uma moralidade refinada que os escritores escoceses do século XVIII como [Henry] Mackenzie e [John] Millar consideravam tão cruciais para uma sociedade complexa. O amor "transformado em amizade" provia a base sobre a qual a sociabilidade e a civilização se estabeleceriam.

A aposta no amor conjugal como fonte de sentimentos sociais implica, como técnica de governo, não apenas uma renovação da concepção de amor que perpassa tratados filosóficos (Millar, 1818 e 1960; Dwyer, 1998:96 e 97) e romances da época (Mackenzie, 1979; Ramsay, 1899). Implica igualmente uma valorização do casamento e uma nova partilha das funções e virtudes dos gêneros envolvidos. $\mathrm{O}$ casamento se converte em sancionador moral do laço amoroso, passando a ser fundado no afeto e na amizade recíprocos. $\mathrm{O}$ amor honrado substitui assim alianças de parentesco e de estamento como critério de casamento, convertendo-se no princípio profundamente enraizado da sociedade (Dwyer, 1998:113). Dentro do matrimônio, é atribuída à mulher a responsabilidade por manter o afeto aceso. Cabe a ela moldar a selvagem atração sexual em uma paixão leve e gentil, governando o homem por 
meio de habilidades como compreensão, simpatia e maturidade. Este seria o único "governo permitido ao nosso lado", como afirmava uma personagem feminina do romance Julia de Robigné de Mackenzie (1979, I:187). A virtude feminina, antes relacionada apenas à castidade e à submissão, desloca-se para atributos como complacência, afabilidade e delicadeza. Em seu temperamento apropriado, cabe também a percepção dos filhos como fonte de prazer e o dever de conduzi-los corretamente, fazendo do seu cuidado uma alegria. Há ainda a incumbência de zelar pela economia doméstica, poupando tanto quanto possível, de modo a ganhar o respeito e se assegurar do amor masculino. Neste novo papel doméstico atribuído à mulher, o amor aparece em romances como de Allan Ramsay, The Gentle Shepherd, como algo mais mental do que físico, que pode por isso mesmo ser manipulado pela delicada arte de agradar. Ao homem, inversamente, resta a tarefa bem mais simples de respeitar sua esposa e lhe conceder o status de amiga, procurando manter a constância estoica aplicada a seus novos sentimentos, afastando-se assim da galanteria. Este deslocamento do papel masculino seria indissociável da própria redefinição da aristocracia guerreira, cuja agressividade combatente deveria ceder espaço à formação cultivada, às maneiras rebuscadas e à eficiência dos novos gestores do Estado.

O casamento, a arte de governo gentil e o laço afetivo familiar convertiam-se, assim, em substitutos da pastoral religiosa e do poder soberano na constituição de uma sensibilidade apropriada a um corpo social autônomo, mas ainda estruturado em estamentos. Considerada por John Millar como tendo início no código cavalheiresco do período Gótico, a ética do amor combinaria a estratificação medieval com "sentimentos e afeições, que são de grande consequência para o intercurso geral da sociedade, ao mesmo tempo em que para a felicidade dos indivíduos" (Millar, 1818, I:119). Mesmo que a ideia do casamento amoroso pudesse subverter a lógica das alianças estamentais, como este amor era compreendido como algo calmo, da ordem do mental e constituído a partir de relações de convivência de longo prazo, e não em termos de atração sexual e paixão repentina, ele favorecia, de fato, relações entre pessoas de mesmo status. Para Millar, as maneiras e instituições cavalheirescas teriam deixado sua marca no gosto e sentimento europeus até a Idade Moderna. A coesão social seria garantida, assim, pela deferência, educação e harmonia que o amor conjugal acabaria por transferir para os laços sociais cotidianos que mantinham a comunidade unida, espraiando os sentimentos sociais do âmbito doméstico privado 
para o público da nação por intermédio das relações de amizade na vizinhança e grupos próximos de pertencimento.

\section{Sentimentos Sociais}

A última fonte de sentimentos morais que emergiu expandindo a lógica do amor conjugal para grupos mais amplos de pertencimento foi a da sociabilidade inerente à natureza humana. Esta substituição é inseparável da própria constituição da noção de sociedade civil por teóricos como Adam Ferguson e de uma importante inflexão antropológica: quando os sentimentos morais tornaram-se sentimentos sociais, o homem social se contrapõe ao sujeito de interesse, sendo a existência da sociedade fundada em propensões instintivas da humanidade. Para Ferguson, os homens são naturalmente sociais, não havendo qualquer período da história anterior ao surgimento da sociedade. "A humanidade deve ser tomada em grupos, como ela sempre subsistiu", por isso "a história do indivíduo é um detalhe dos sentimentos e pensamentos que ele tem acalentado na visão de sua espécie: e todo experimento relativo a este tema deve ser feito com sociedades inteiras, não com um único homem" (Ferguson, 1995:10).

A sociabilidade da natureza humana estaria assentada em três princípios instintivos que antecedem as percepções de prazer e dor e a experiência do que é pernicioso ou útil. Primeiro, um princípio da autopreservação que conduziria o homem à vida em sociedade para satisfazer o conjunto dos seus apetites e a continuação da espécie. Como no ser humano esse princípio instintivo pode se combinar com a reflexão e a providência, dando forma ao interesse, dependendo do grau em que ele se desenvolve, pode conduzir a uma corrupção antissocial, na qual a busca desregrada pelo interesse pode levar o indivíduo à violência e à mesquinharia (ibidem:17). Segundo, um princípio de união, assentado em "paixões desinteressadas" que poderiam levar a agir em sentido oposto ao interesse, sem esperanças de compensação futura na forma de nomeação ou lucro (ibidem:20-21). Esse princípio instintivo, não racionalista, de formação da sociedade, baseava-se em três propensões naturais: a afeição parental; a propensão a se misturar ao rebanho e, sem reflexão, seguir a multidão de sua espécie; e, por fim, o sentimento de ligação e pertencimento ao grupo. Tal ligação do homem ao grupo é vista, conforme Ferguson, como uma fonte de energia extra, já que a vida em sociedade despertaria uma variedade de forças "emocionais" capazes de levar os homens a se esquecerem de suas fraquezas, das 
preocupações com sua segurança e subsistência em nome do sacrifício ao grupo (ibidem:23). Dessa fonte emocional da vida em sociedade derivariam inclusive as faculdades do caráter propriamente humano, como a racionalidade e a felicidade (ibidem). Terceiro, um princípio de dissenso que, ao lado da corrupção dos interesses, poderia explicar as lutas e disputas entre os homens. Ao contrário do interesse, que explicaria as disputas individuais, o dissenso seria complementar ao princípio da união e daria conta dos desentendimentos entre os grupos humanos: a luta contra uma tribo externa é derivada e reforça a coesão interna do próprio grupo (ibidem:24-29).

Os sentimentos morais estão associados à disposição social humana derivada do princípio de união e permitem aos homens, como espectadores ou atores, diferenciar as condutas e classificar os caracteres dos semelhantes, constituindo, juntamente com os poderes da deliberação e da razão, a base de nossa natureza moral (ibidem:36). A sensação de prazer derivada da aprovação dos sentimentos morais às ações benevolentes ajudam os seres humanos a fazerem as "escolhas corretas" e constituem-se como as verdadeiras fontes da felicidade humana. Não seria, portanto, nos prazeres sensuais solitários que o homem encontraria sua alegria, pois, quando elevados a determinados graus, os cuidados com a preservação animal causavam ansiedade dolorosa e paixões cruéis hostis ao bem-estar da humanidade (ibidem:54). A felicidade humana, como telos do governo da conduta, não está associada apenas a satisfações sensuais, mas, sobretudo, à sociabilidade e à conduta ética altruísta. Desse modo, os sentimentos morais não descreviam apenas uma propensão humana, apresentavam também um caráter normativo que auxiliava nas decisões, sem, contudo, determiná-las inteiramente (pois ainda restavam as propensões egoístas derivadas da corrupção do interesse). Foi, então, com base nos sentimentos morais que o pertencimento à comunidade, incluindo uma subordinação hierárquica histórica e instintivamente (não racionalmente) estabelecida (ibidem:121-135), foi prescrito em nome do bem comum.

Em Ferguson, o caráter social dos sentimentos morais pode ser compreendido em um duplo registro. Por um lado, os sentimentos morais foram concebidos com base na análise das propensões instintivas do indivíduo e de sua natureza humana apresentada em termos eminentemente sociais (se bem que passível de corrupção): o indivíduo é tido como parte do todo, como um membro da sociedade. Por outro lado, a vida em sociedade é tida como produtora de sentimentos intensos 
capazes de dar sustentação e discernimento morais para o indivíduo, é vista como a fonte que permite a ele não apenas satisfazer da melhor maneira possível as suas necessidades animais, mas sobretudo as propriamente humanas, desenvolvendo suas faculdades como a razão e a felicidade. Fora da sociedade, na solidão, o homem aparecia como uma "planta afastada da sua raiz", um animal decaído longe do seu caráter e personagem humano (ibidem:30).

Pela primeira vez com Ferguson, portanto, o ser humano emerge como homo socialis, cujas necessidades e desenvolvimento são indissociáveis da vida em sociedade. A sociedade substitui o senso moral e a simpatia como fonte de energias "emocionais" que sustentam a moral, a razão, a felicidade e as demais faculdades propriamente humanas dos indivíduos. A sociedade, deste modo, surgia como antecedendo histórica, lógica, ética e politicamente o indivíduo, sendo este antes o produto do que o elemento constitutivo originário da sociedade.

\section{Os Sentimentos Sociais e a Comunidade de Pertencimento}

Há, em Ferguson, uma crítica normativa às intensas mudanças sociais e materiais do século XVIII, particularmente em relação aos efeitos econômicos sobre a virtude, a comunidade e os laços afetivos da vida social. Para o autor, a sociedade civil não podia ser reduzida às relações de mercado, podendo o mercado conter as raízes do despotismo. De fato, desde a Guerra dos Sete Anos, houve uma alteração nos discursos de autores escoceses como Adam Ferguson, Thomas Reid, James Beattie, Henry Mackenzie e Hugh Blair que, de uma celebração da melhora iluminista da comunidade moral, passaram a uma defesa de seus valores ameaçados. Mesmo para autores mais otimistas o perigo se apresentava. Millar, por exemplo, considerava que a difusão dos laços econômicos, com sua consequente imoderação do interesse, da busca do prazer sensual, da luxúria e da ambição, levaria a um declínio natural da propensão masculina a assumir as responsabilidades do casamento e da família e, consequentemente, a um aumento da galanteria e da prostituição e a um recrudescimento da simpatia e da benevolência (Millar, 1818, IV:217-230). Até mesmo Adam Smith passou a considerar que, ao lado da ameaça representada pelo fanatismo religioso, o perigo do luxo e da admiração pelos ricos e poderosos também colocava em risco a moral e a nação.

A discussão a respeito da comunidade se tornou, assim, tanto descritiva como normativa, com a prescrição de uma expansão dos laços afeti- 
vos do âmbito privado para o público de modo a reagir contra o egoísmo do que era percebido como uma sociedade artificial de atores interessados. Esta normatividade, no entanto, oscilava entre uma posição mais conciliatória com relação às transformações modernas e uma postura mais precavida e mais reativa em relação a elas (Dwyer, 1998:178-179).

Neste último caso, o texto polemicamente atribuído a James Macpherson intitulado The Poems of Ossian teve um papel fundamental. A construção de um retrato mítico de um passado nacional de integração sentimental com seus heróis refinados, esclarecidos e afetivos foi o dispositivo para a produção de uma nostalgia que vinculava "emocionalmente" os indivíduos à sua pátria. Forjado com o objetivo de preservar os laços de comunidade e a identidade nacional escocesa contra o império comercial britânico, tornou-se amplamente popular em sua época e conquistou sucesso internacional. Noções como the joy of griefe morality of memory produziam uma absorção do passado patriótico em um presente sentimental, formando uma ética da sociabilidade afetiva. A melancolia reflexiva à qual o poema recorria despertava no leitor compaixão e simpatia social, reduzindo o egoísmo e produzindo uma identificação humana. Memória e melancolia não visavam à produção de autoindulgência, mas, por meio de uma comunidade idealizada em um passado remoto, ao estímulo aos laços coletivos. Nesse sentido, o próprio poema e os discursos do mesmo gênero que o seguiram podem ser vistos como dispositivos "emocionais", cujas técnicas literárias, de oratória e rituais deslocaram a percepção da nação do âmbito políticoinstitucional para o de um ideal sentimental de comunidade (Dwyer, 1998:182-188).

Este mesmo ideal de comunidade sentimental está presente na crítica que Edmund Burke fez à Revolução Francesa e que posteriormente foi apropriado por diferentes correntes do conservadorismo. Localizando sua origem, tal como Millar, na época do antigo cavalheirismo e estendendo sua influência por uma longa sucessão de gerações até formar o caráter da Europa moderna, Burke temia que se esse sistema misto de opiniões e sentimentos desaparecesse em função de sua substituição pela lógica dos sofistas, economistas e calculadores, a perda seria enorme. Os sentimentos sociais seriam responsáveis pela "generosa lealdade entre estamentos e sexos", por "aquela orgulhosa submissão, aquela obediência digna, aquela subordinação do coração, que mantêm viva, mesmo na própria servidão, o espírito de uma liberdade 
exaltada", pela "produção da nobre igualdade" que se espalhava por "todas as gradações da vida social" sem "confundir estamentos", pela "graça não paga da vida", pela "defesa gratuita das nações", pelos "empreendimentos heroicos", pelo "enobrecimento do que quer que tocasse", fazendo até o "vício perder metade de seu perigo pela perda de sua brutalidade" (Burke, 2003 [1790]:65-66). Nova operacionalidade atribuída aos sentimentos, eles permitiam que a liberdade e a igualdade fossem reduzidas às dimensões afetiva e moral internas, seja como forma de desenvolvimento da personalidade que não excluía a disciplina externa ou como felicidade compartilhada pela integração afetiva em uma comunidade estruturada hierarquicamente (ibidem:32, 208). Os sentimentos se tornavam responsáveis pela incorporação das instituições, das leis, da subordinação e das desigualdades apresentadas como naturais (ibidem:66).

Se por um lado os sentimentos garantiam a "obediência liberal" dos súditos, por outro, acreditava Burke, asseguravam a "gentileza do poder", o que se dava por meio da submissão dos soberanos "ao laço suave da estima social", das autoridades "à elegância" e do "dominante vencedor pelas leis" às "maneiras". Especialmente os sentimentos religiosos seriam importantes no reforço dos princípios morais que colocariam limites ao egoísmo e aos abusos dos que possuem alguma forma de poder na sociedade (ibidem:79-84). Os sentimentos garantiriam, assim, a "harmonização dos diferentes papeis da vida" e a "incorporação no político dos sentimentos que embelezam e aliviam a sociedade privada" (ibidem:65-66).

O fim da sensibilidade e do refinamento produzidos pelos princípios da gentileza aristocrática e da religiosidade do clero levaria à tirania, sendo as leis impostas somente por seu terror, sem nada engajar de afeição em prol do bem comum. Na filosofia mecânica dos revolucionários franceses, as instituições nunca seriam incorporadas pelas pessoas, e, sem "criar em nós amor, veneração, admiração ou vinculação", "esta sorte de razão que bane o afeto [se tornaria] incapaz de preencher seu lugar" (ibidem:66). A Revolução Francesa representaria, assim, "a mais importante de todas as revoluções", ou seja, "uma revolução em sentimentos, maneiras e opiniões morais" (ibidem:69). E, no entender de Burke, uma revolução de modo algum positiva, na medida em que desfaria os afetos públicos e as maneiras que auxiliam as leis e que permitiam que o país se tornasse amado por seus habitantes (ibidem:66). 


\section{OS SENTIMENTOS MORAIS COMO ESTRATÉGIA DE GOVERNO "EMOCIONAL"}

No governo britânico do século XVIII, o discurso dos sentimentos morais e as estratégias de poder "emocional" ligadas a ele procuraram, no âmbito de uma Razão de Estado parlamentar vitoriosa, limitar o poder soberano do Rei, constituindo um corpo social autônomo e pacificado em relação às guerras religiosas. Colocando-se como moderador ou como alternativa a outra forma de integração social autônoma, qual seja, a dos laços de interesse, os seus formuladores buscavam reabilitar a regra emocional cristã do amor benevolente em contraposição ao amor-próprio. Seu discurso reintroduziu os julgamentos morais altruístas como forças "emocionais", permitindo-lhes disputar o sentido das condutas humanas com as paixões.

Novos dispositivos de subjetivação desta regra emocional foram então forjados, constituindo as bases afetivas da emergente concepção de sociedade civil. Com exceção do senso moral, que operou uma transição teórica, as demais fontes traçavam táticas e definiam operadores: a simpatia definia uma técnica de si que responsabilizava o próprio sujeito pela sua regulação afetiva; o amor conjugal deslocava para o governo feminino e sua arte de agradar a missão de desenvolver no âmbito doméstico e familiar (e para além dele) os sentimentos sociais; a vida social deslocava para a comunidade nacional ou para os grupos de pertencimento a promoção de uma ética da sociabilidade sentimental, por meio de mitos e rituais. Nesses diferentes mecanismos, os sentimentos eram quase sempre apresentados como algo que se recebia de fora, seja da transmissão da "emoção" de outro indivíduo seja da comunidade. Em última instância, os sentimentos morais eram passivos para permitirem a influência afetiva do outro, a qual agia sobre o sujeito como força interna. Este homem social, em que a felicidade dos outros era elemento constituinte da própria subjetividade, instituía uma ordem social baseada em laços morais e de solidariedade.

A emergência da noção de sentimentos morais vinculada com a de sociedade civil pode oferecer caminhos interessantes de investigação. Por um lado, ela permite uma análise do governo britânico do século XVIII tendo como chave de leitura a influência do poder "emocional". Por outro, ela nos ajuda a entender a formulação da própria concepção de sociedade presente em textos clássicos de sociologia. Como alguns desses textos permanecem operacionais até hoje, informando práticas 


\section{Daniel Pereira Andrade}

de subjetivação, como no caso da apropriação dos textos de Émile Durkheim pelas ciências da gestão contemporâneas, a genealogia dos sentimentos morais abre caminho para uma história das maneiras contemporâneas de sentir.

(Recebido para publicação em janeiro de 2012)

(Reapresentado em maio de 2014)

(Aprovado para publicação em junho de 2015) 


\section{REFERÊNCIAS BIBLIOGRÁFICAS}

ARMSTRONG, Nancy ; TENNENHOUSE, Leonard. (2006), “A Mind for Passion: Locke and Hutcheson on Desire", in V. Kahn; N. Saccamano e D. Colli (eds.), Politics and the Passions, 1500-1850. Princeton, Princeton University Press, pp. 131-150.

AUERBACH, Erich. (1998), “De la Passio aux Passions”, in Le Culte des Passions. Essais sur le XVIe Siècle Français. Paris, Macula, pp. 51-81.

BACON, Francis. (2000) [1625], The Essays or Conseuls, Civil and Moral. Oxford, Clarendon Press.

BAERTSCHI, Bernard. (2003), "Senso Moral (Senso Moral e Consciência Moral)”, in M. Canto-Sperber (org.), Dicionário de Ética e Filosofia Moral. São Leopoldo, Ed. Unisinos, vol. II, pp. 558-566.

BERMON, Emmanuel. (2003), “La Théorie des Passions Selon Saint Agustin”, in B. Besnier; P.-F. Moreau e L. Renault (eds.), Les Passions Antiques et Médiévales. Paris, PUF.

BURKE, Edmund. (2003) [1790]. Reflections on the Revolution in France. New Haven/London, Yale University Press.

CHARRON, Pierre. (1986), De la Sagesse. Paris, Fayard.

CLÉRO, Jean-Pierre. (2003), "Simpatia”, in M. Canto-Sperber (org.), Dicionário de Ética e Filosofia Moral. São Leopoldo, Ed. Unisinos, vol. II, pp. 585-590.

DIXON, Thomas. (2003), From Passions to Emotions. The Creation of a Secular Psychological Category. Cambridge, Cambridge University Press.

DWYER, John. (1998), The Age of Passions. East Linton, Tuckwell Press.

FERGUSON, Adam. (1995), An Essay on the History of Civil Society. Cambridge, Cambridge University Press.

FOUCAULT, Michel. (1990), “Tecnologías del Yo”, in M. Morey (ed.), Tecnologías del Yo, y otros Textos Afines. Barcelona, Paidós/ICE-UAB, pp. 95-140.

. (1995), “O Sujeito e o Poder", in H. Dreyfus e P. Rabinow (eds.), Michel Foucault, uma Trajetória Filosófica (para Além do Estruturalismo e da Hermenêutica). Rio de Janeiro, Forense Universitária, pp. 231-249.

. (2004a), Sécurité, Territoire, Population - Cours au Collège de France (1977-1978). Paris, Seuil/Gallimard.

. (2004b), Naissance de la Biopolitique : Cours au Collège de France (1978-1979). Paris, Seuil/Gallimard.

HARRÉ, Rom. (1986), The Social Construction of Emotions. Oxford, Basil Blackwell.

HIRSCHMAN, Albert. (1980), Les Passions et les Intérêts. Paris, PUF.

HOBBES, Thomas. (1997) [1651], Leviathan. New York, Norton.

HOCHSCHILD, Arlie. (2003), The Commercialization of Intimate Life: Notes from Home and Work. Berkeley, University of California Press.

HUME, David. (2001), Tratado da Natureza Humana: Uma Tentativa de Introduzir o Método Experimental de Raciocínio nos Assuntos Morais. São Paulo, Editora Unesp e Imprensa Oficial do Estado. 


\section{Daniel Pereira Andrade}

HUTCHESON, Francis. (1996), “Uma Investigação sobre o Bem e o Mal do ponto de vista da Moral"; "Ensaio sobre a Natureza e Conduta das Paixões e Afetos"; "Ilustração sobre o Senso Moral", in J. Butler et al. (eds.), Filosofia Moral Britânica: Textos do Século XVIII. Campinas, Editora da Unicamp, pp. 111-182.

KLIBANSKY, Raymond; PANOFSKY, Erwin; SAXL, Fritz. (1989), Saturne et la Mélancolie. Paris, Gallimard.

LA ROCHEFOUCAULD, François de. (1992), “Réflexions ou Sentences et Maximes Morales et Réflexions Diverses", in J. Lafond (ed.), Moralistes du XVIIe siècle. Paris, Robert Laffont, pp. 134-232.

LAZZERI, Christian. (1992), “Le Gouvernement de la Raison d'État”, in C. Lazzeri; D. Reynié (eds.), Le Pouvoir de la Raison d'État. Paris, PUF, pp. 91-134.

LEVI, Anthony. (1964), French Moralists. The Theory of the Passions 1585 to 1649. Oxford, Oxford University Press.

LIPSE, Juste. (1994), Les Politiques - Livre IV. Caen, Presse Universitaire de Caen.

(2010), Sobre la Constancia. Cáceres, Universidad de Extremadura.

LOCKE, John. (1987) [1689], An Essay Concerning Human Understanding. Oxford, Clarendon.

MACKENZIE, Henry. (1979), Julia de Robigné. New York, Birlinn.

MANDEVILLE, Bernard. (1934) [1714], The Fable of the Bees: Or, Private Vices, Public Benefits. London, Wishart \& Company.

. (1996), "Uma Investigação sobre a Origem da Virtude Moral", in J. Butler et al. (eds.), Filosofia Moral Britânica: Textos do Século XVIII. Campinas, Editora da Unicamp, pp. 77-86.

MANENT, Pierre. (1987), Histoire Intelectuelle du Libéralisme. Paris, Hachette.

MILLAR, John. (1818). An Historical View of the English Government. London, J. Mawman Publication.

(1960), "The Origin of the Distinction of Ranks", in John Millar of Glasgow, 1735-1801. Cambridge, Cambridge University Press, pp. 162-322.

MOREAU, Pierre-François. (2003), “Les Passions: Cotinuités et Tournants", in B. Besnier; P.-F. Moreau e L. Renault (eds.), Les Passions Antiques et Médiévales. Paris, PUF, pp. 1-12.

MOSSE, George. (1957), The Holy Pretense. Oxford, Basil Blackwell.

MULLAN, John. (1988), Sentiment and Sociability. The Language of Feeling in the Eighteenth Century. Oxford, Oxford University Press.

NICOLE, Pierre. (1999), Essais de Morale. Paris, PUF.

QUILLIET, Bernard. (2007), L'Acharnement Théologique: Histoire de la Grâce en Occident, IIIe-XXIe Siècle. Paris, Fayard.

RAMSAY, Allan. (1899), The Gentle Shepherd: A Pastoral Comedy. London, Adam and Charles Black.

SANTO AGOSTINHO. (1962), "De Corruptione et Gratia”, in CEuvres. Paris, Desclée de Brouwer. 


\section{O Governo dos Sentimentos Morais no Século XVIII}

(2000), "Cité de Dieu", in CEuvres. Paris, Gallimard, tomo II.

(2002), "La Grâce et le Libre Arbitre”, in OEuvres. Paris, Gallimard, tomo III.

SENAULT, Jean-François. (1987). De l'Usage des Passions. Paris, Fayard.

SENELLART, Michel. (1989), Machiavélisme et Raison d'État: XIIe-XVIIIe Siècle. Paris, PUF.

(1995), Les Arts de Gouverner. Paris, Seuil.

SHAFTESBURY, Lord. (1996), “Uma Investigação Acerca da Virtude ou do Mérito”, in J. Butler et al. (eds.), Filosofia Moral Britânica: Textos do Século XVIII. Campinas, Editora da Unicamp, pp. 13-36.

SMITH, Adam. (1988), Investigação sobre a Natureza e as Causas da Riqueza das Nações. São Paulo, Nova Cultural.

(1999), Teoria dos Sentimentos Morais. São Paulo, Martins Fontes.

TALON-HUGON, Carole. (1999), “Affectivité Stoïcienne, Affectivité Salésienne”, in P.-F. Moreau (ed.), Le Stoïcisme au XVIe et au XVIIe Siècle. Le Retour des Philosophies Antiques à l'Âge Classique. Paris, Albin Michel, Tomo I, pp. 175-188.

(2002), Les Passions Rêvées par la Raison. Paris, Vrin.

TERESTCHENKO, Michel. (2009), Amour et Désespoir. De François de Sales à Fénelon. Paris, Seuil.

THUAU, Étienne. (2000), Raison d'État et Pensée Politique à l'Époque de Richelieu. Paris, A. Michel.

WASZEK, Norbert. (1988), Man's Social Nature: a Topic of the Scottish Enlightenment in its Historical Setting. Frankfurt am Main; Bern; New York; Paris, Lang.

. (2003), L'Écosse des Lumières. Hume, Smith, Ferguson. Paris, PUF.

WRIGHT, Thomas. (1986), The Passions of the Mind in General. New York/London, Garland. 


\section{Daniel Pereira Andrade}

\section{RESUMO}

\section{O Governo dos Sentimentos Morais no Século XVIII}

O presente artigo realiza uma história da noção de sentimentos morais na governamentalidade britânica do século XVIII e de sua estratégia de poder "emocional", a qual difere de outras concepções gerais de vida "emocional", como a de paixões do século XVII. Partindo do construcionismo social das emoções, busca-se compreender como os discursos e as técnicas de poder moldam a maneira de sentir. Com este fim, são explicadas suas fontes causadoras (senso moral, simpatia e sociedade), como se relacionam com as demais faculdades da mente (julgamentos morais, razão, imaginação e memória), com o corpo (sensorial de dor e prazer) e como determinam as condutas. Após este percurso, argumenta-se que o discurso dos sentimentos morais constituiu um poder emocional caracterizado por determinados objetos (julgamentos morais), técnicas (simpatia, arte de agradar feminina e mitologização da comunidade nacional), finalidades (desenvolvimento da personalidade atrelado à integração grupal) e regras emocionais (prescrição do amor benevolente e moderação do amor de si) e expressivas (manifestações de solidariedade).

Palavras-chave: sentimentos morais; paixões; governamentalidade; poder emocional; vida emocional

\section{ABSTRACT \\ The Government of Moral Sentiments in the Eighteenth Century}

This article presents a history of the notion of moral sentiments in British governmentality in the eighteenth century and its strategy of "emotional" power, which is distinct from other general conceptions of "emotional" life, such as the life of passions current in the seventeenth century. Building upon the social constructionism of emotions, the article strives to understand how the discourses and technique of power shape feelings. With this in mind, their sources (moral sense, sympathy and society), how they relate to other faculties of the mind (moral judgment, reason, imagination and memory), with the body (sensory pain and pleasure) and how they determine conducts. After presenting these developments, the article argues that the discourse of moral sentiments constituted an emotional power defined by certain objects (moral judgment), techniques (sympathy, the feminine art of pleasing and the mythologization of national community), finalities (development of the personality linked to group integration) and emotional rules (the recommendation of benevolent love and the moderation of self-love) and of expressions (manifestations of solidarity).

Keywords: moral sentiments; passions; governmentality; emotional power; emotional life 


\section{RÉSUMÉ}

\section{Le Gouvernement des Sentiments Moraux au XVIII ${ }^{\text {ème }}$ Siècle}

Le présent article retrace l'histoire de la notion de sentiments moraux au sein de la gouvernementalité britannique du XVIII ${ }^{\text {ème }}$ siècle, dont la stratégie de pouvoir "émotionnel" différait des autres conceptions générales de vie "émotionnelle", comme celle des passions du XVII ${ }^{\text {ème }}$ siècle. Sur la base du constructivisme social des émotions, nous chercherons à comprendre de quelle manière les discours et les techniques du pouvoir influent sur le ressenti. Seront explicitées à cette fin les causes de ces émotions (sens moral, sympathie et société), ainsi que la façon dont elles sont liées à d'autres facultés de l'esprit (jugements moraux, raison, imagination et mémoire) et au corps (sensations de douleur et de plaisir), et dont elles déterminent les conduites. Nous défendrons ensuite que le discours des sentiments moraux a permis de construire un pouvoir émotionnel caractérisé par des objets (jugements moraux), des techniques (sympathie, art féminin du "faire plaisir" et mythologisation de la communauté nationale), des finalités (développement de la personnalité lié à l'intégration au groupe) et des règles émotionnelles (prescription de l'amour bienveillant et modération de l'amour de soi) et expressives (manifestations de solidarité).

Mots-clés: sentiments moraux; passions; gouvernementalité; pouvoir émotionnel; vie émotionnelle

\section{RESUMEN}

\section{El Gobierno de los Sentimientos Morales en el Siglo XVIII}

Este artículo reconstruye una historia de la noción de sentimientos morales en la gubernamentabilidad británica del siglo XVIII y de su estrategia de poder "emocional", la cual difiere de otras concepciones generales de la vida "emocional", como la de pasiones del siglo XVII. A partir del construccionismo social de las emociones, se busca comprender cómo los discursos y las técnicas de poder forjan la manera de sentir. Con este fin, se explican sus fuentes causadoras (sentido moral, simpatía y sociedad), sus relaciones con las demás facultades de la mente (juicios morales, razón, imaginación y memoria), del cuerpo (sensación de dolor y de placer), bien como los determinantes de las conductas. Se argumenta que el discurso de los sentimientos morales constituyó un poder emocional caracterizado por determinados objetos (juicios morales), técnicas (simpatía, arte femenina de agradar y mitologización de la comunidad nacional), finalidades (desarrollo de la personalidad vinculada a la integración grupal) y reglas emocionales (prescripción del amor benevolente y moderación del amor de sí) y expresivas (manifestaciones de solidaridad).

Palabras clave: sentimientos morales; pasiones; gubernamentalidad; poder emocional; vida emocional 